\title{
CRYSTALLISATION CONDITIONS OF IGNEOUS EPIDOTE IN A METAMORPHIC SOLE FROM NEOTETHYAN OPHIOLITIC MELANGE, KONYA, CENTRAL SOUTHERN TURKEY.
}

DOI: http://dx.doi.org/10.18509/GBP.2019.07

UDC: 552.31:552.43.051(560)

\author{
Kerim Kocak \\ Raziye Merve Kaya \\ Konya Technical University, Faculty of Engineering and Natural Sciences, \\ Department of Geological Engineering, Turkey
}

\begin{abstract}
Subhedral to euhedral epidote occurs with compositional and sector zoning in a metamorphic sole at the bottom of a Neotethyan ophiolitic mélange. The epidote is characterised by low $\mathrm{Fe}_{2} \mathrm{O}_{3}(5-8 \%)$, high $\mathrm{Al}_{2} \mathrm{O}_{3}$ (26-30\%), and minor $\mathrm{TiO}_{2}(0.05-0.18$ $\mathrm{wt} \%), \mathrm{MnO}(0.01-0.1 \mathrm{wt} \%)$ and $\mathrm{MgO}(0-0.12 \mathrm{wt} \%)$ contents. Petrographical and mineralogical characteristics and various aluminium-in- hornblende geobarometry estimates suggest that the amphibole associated with epidote was possibly crystallized from a wet tholeiitic/alkaline magma between $\sim 3.5-7 \mathrm{~kb}$ pressure conditions.
\end{abstract}

Keywords: Igneous epidote, ophiolite, metamorphic sole, Turkey

\section{INTRODUCTION}

Epidote can be formed by medium-temperature alterations [1] and high pressure metamorphism [2] as well as by magmatism with various chemical compositions [3], [4], [5]. Metamorphic sole units at the base of Neotethyan ophiolitic mélange in the SW part of Konya city (Figure 1) contains metabasic rocks, namely, amphibolite, epidoteamphibolite, zoizit-amphibolite, garnet-amphibole schist, amphibole schist, plagioclase amphibole schist, plagioclase-epidote-amphibole schist and q-amphibole schist. The metabasic rocks were represent oceanic crust, with alkaline and tholeiitic affinities [6], which were undergone a regional metamorphism in greenschist facies conditions, as evidenced by existence of chlorite and albite association. Subhedral to euhedral widespread epidote crystals occurs with compositional and sector zoning in the metamafic rocks. Present study aims to study the epidote minerals with determining its crystallizing conditions.

\section{MATERİAL\&METHODS}

Twenty-six petrographic thin sections were studied under the microscope to determine composition and texture. Polished sections $\left(25^{*} 46 \mathrm{~mm}\right)$ of representative rock samples were made at the thin-section Laboratory of MTA-Ankara. Polished slides were coated with carbon and then analyzed at the Electron Microprobe Laboratory of Middle East Technical University, Ankara/TURKEY. Mineral analyses were performed on a JEOL JSM35 Electron Microprobe running Link QX2000 energy dispersive analytical software. 


\section{PETROGRAPHY \&MINERAL CHEMISTRY}

The subhedral to euhedral epidote (sensu lato) $(0.1-0.4 \mathrm{~mm}, 23.5-38.4 \%)$ forms as a single grain preceded by pyroxene, or rarely in aggregate. It resorbs and truncates an optically continuous amphibole, suggesting an igneous origin for epidote [9].

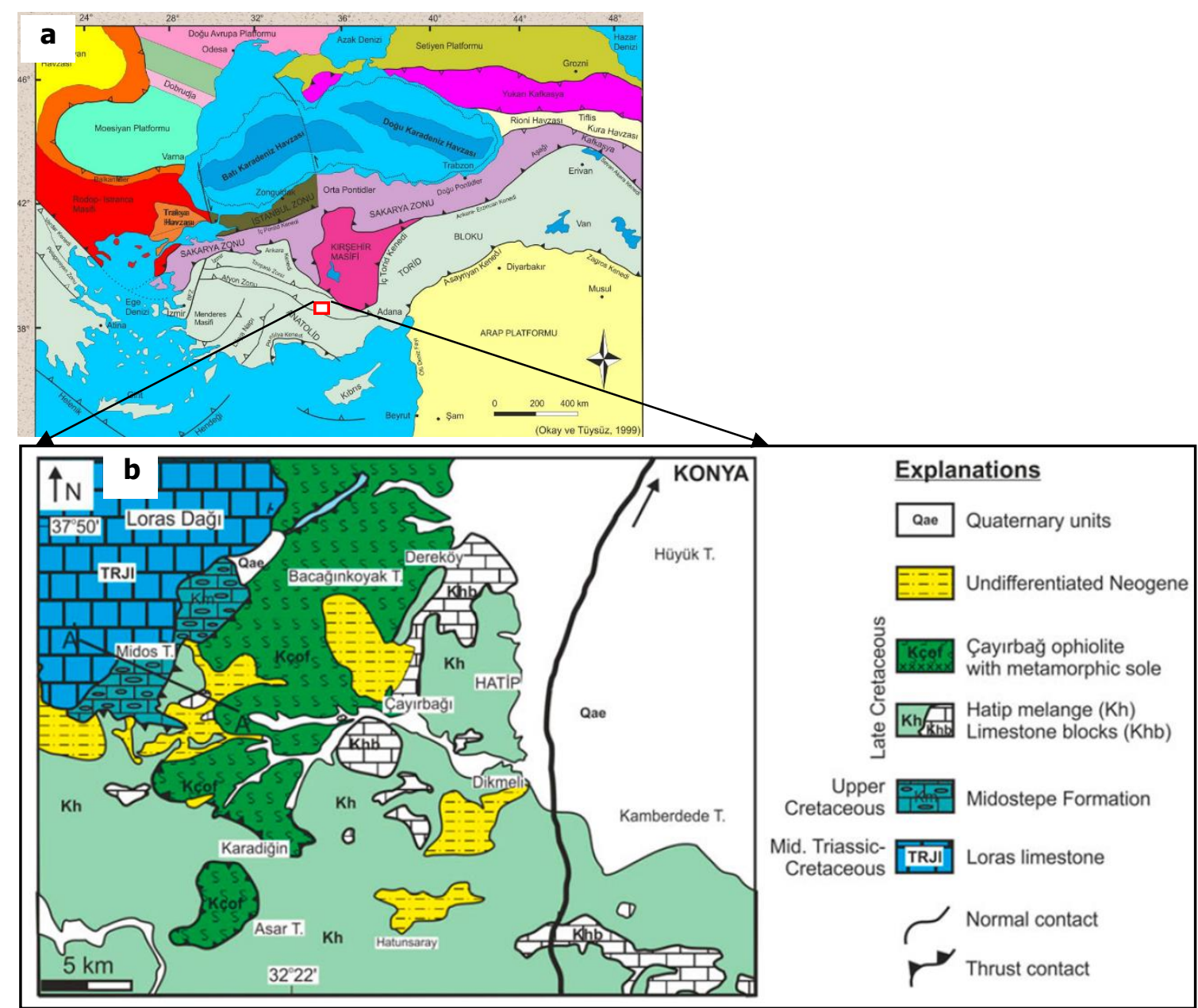

Figure 1: a) Tectonic units of Turkey [7] b) Geological map of the study area [8]

The epidote minerals were analysed by electron microprobe at METU, Ankara (Turkey). The epidote is characterised by low $\mathrm{Fe}_{2} \mathrm{O}_{3}(5-8 \%)$, high $\mathrm{Al}_{2} \mathrm{O}_{3}(26-30 \%)$, and minor $\mathrm{TiO}_{2}$ (0.05-0.18 wt \%), $\mathrm{MnO}(0.01-0.1 \mathrm{wt} \%)$ and $\mathrm{MgO}(0-0.12 \mathrm{wt} \%)$ contents. The epidote crystals are mainly zoisite $\left[\mathrm{Xcz}:\left(\mathrm{Al}^{3+}-2\right) /\left(\mathrm{Fe}^{3+}+\mathrm{Al}^{3+}-2+\mathrm{Cr}^{3+}\right)\right]$ in composition, ranging from $\mathrm{Xcz}=0.46-0.72$ whilst epidote composition [Xep: $\mathrm{Fe}^{3+} /\left(\mathrm{Fe}^{3+}+\mathrm{Al}^{3+}-2+\right.$ $\left.\mathrm{Cr}^{3+}\right)$ ] also exists, with Xep $=0.27-0.53$.

\section{DISCUSSION\&CONCLUSIONS}

The epidote is subhedral to euhedral (Error! Reference source not found.), and embays and truncates an optically continuous amphibole, suggesting an igneous origin for epidote. $\mathrm{TiO}_{2}$ contents of the samples range from 0.05 to $0.31 \mathrm{wt} \%$, but mostly less than $0.2 \mathrm{wt} \%$, also confirming an igneous origin [10]. 
To constrain crystallisation pressure of the epidote, various Al-in-hornblende geobarometers used for the amphiboles associated with epidote. High NaM4 and Aliv contents of the amphiboles that associated with epidote suggest high pressure condition (up to $7 \mathrm{kbar}$ ) for their crystallisation. Various Al-in-hornblende geobarometers (Table 1) give variable crystallisation results, ranging from 2.1 to $9 \mathrm{~kb}$. [11] and Thomas 1990 [12] geobarometer gives higher and lower pressures, respectively. Taking account the standard deviation of the geobarometer results, the amphibole associated with epidote is likely to be crystallised in a range of pressure ranging from 3.5 to $7 \mathrm{~kb}$. Similar high pressure crystallisation in ophiolitic gabbro is also determined such as cumulate pyroxenite and gabbro of tholeiitic Andaman Ophiolite (7-8.6 kb, Saha et al., 2010) in Andaman-Nicobar Islands, India), hercynite gabbronorite of Sikhote-Alin ophiolites (512 kbar[13] in the Russian Far East.

Modal abundance of amphibole and lack of the water free - mafic minerals, such as olivine and pyroxene in the sample suggest that the epidot and amphibole are likely to be crystallised from $\mathrm{H}_{2} \mathrm{O}$-rich magma, which is substantial in setting epidote in the crystallisation sequence of wet-silicate magmas [14], [15].

Table 1. Results of Al-in hornblende geobarometer calculations. SD: standard deviation

\begin{tabular}{|c|c|c|}
\hline Geobarometers & Results & SD \\
\hline$[16]$ & $3.9-7.3$ & $( \pm 3)$ \\
\hline$[17]$ & $4.03-7.8$ & $( \pm 1)$ \\
\hline$[18]$ & $6.1-9 \mathrm{~kb}$ & $( \pm 0.5)$ \\
\hline$[12]$ & $2.1-5.7$ & $( \pm 1)$ \\
\hline$[19]$ & $4.4-7.6$ & $( \pm 0.6)$ \\
\hline$[20]$ & $3.4( \pm 0.5)-$ & \\
\hline & $6.2( \pm 1 ; \pm 16 \%)$ & \\
\hline
\end{tabular}

\section{REFERENCES}

[1] Chukhrov VV. Minerals, (VV Chukhrov Ed. Vol. 3), Moscow, Nauka, 1972.

[2] Enami M; Liou JG, Mattinson CG. Epidote minerals in high P/T metamorphic terranes: Subduction zone and high- to ultrahigh-pressure metamorphism, Epidotes, vol. 56, pp.347-398, 2004.

[3] Pattnaik SK. Petrology of the Bhela-Rajna alkaline complex, Nuapara District, Orissa, Journal of the Geological Society of India, vol. 48, 1, pp.27-40, 1996.

[4] Owen J. Significance of epidote in orbicular diorite from the Grenville Front zone, eastern Labrador, Mineralogical Magazine, vol. 55, (379), pp.173-181, 1991.

[5] Korinevskii VG. Magmatic epidote from gabbro, Russian Geology and Geophysics, vol. 49, 3, pp.159-164, 2008.

[6] Dasci HT; Parlak O; Nurlu N, Billor Z. Geochemical characteristics and age of metamorphic sole rocks within a Neotethyan ophiolitic melange from Konya region (central southern Turkey), Geodinamica Acta, vol. 27, 4, pp.223-243, 2015.

[7] Okay A, Tüysüz O. Tethyan sutures of northern Turkey. In: Durand B, Jolivet L, Horvárt, Séranne M (eds) The mediterranean basins: tertiary extension within the alpine Orogen, Geological Society London Special Publications, vol. 156, pp.475-515, 1999.

[8] Özcan A; Göncüoğlu MC; Turhan N; Şentürk K; Uysal Ş, Işık A. Konya-Kadınhanı-Ilgın dolayının temel jeolojisi (in Turkish) (1990). MTA Genel Müdürlügü Jeoloji Etütleri Dairesi.

[9] Zen EA, Hammarstrom JM. Magmatic epidote and its petrologic significance, Geology, vol. 12, 9, pp.515-518, 1984. 
[10] Evans BW, Vance JA. Epidote Phenocrysts in Dacitic Dikes, Boulder County, Colorado, Contributions to Mineralogy and Petrology, vol. 96, 2, pp.178-185, 1987.

[11] Johnson GI; Cooper JA, Blight DF. The Geology and Geochronology of a Proterozoic Trachyandesite Plug, Murchison Province, Yilgarn Block, Western Australia, Australian Journal of Earth Sciences, vol. 36, 3, pp.319-336, 1989.

[12] Thomas WM, Ernst WG. The aluminium content of hornblende in calc-alkaline granitic rocks : A mineralogic barometer calibrated experimentally to 12 kbars, Fluid-mineral interactions : A tribute to H.P. Eugster, vol., pp.59-63, 1990.

[13] Khanchuk AI, Vysotskiy SV. Different-depth gabbro-ultrabasite associations in the SikhoteAlin ophiolites (Russian Far East), Russian Geology and Geophysics, vol. 57, 1, pp.141-154, 2016.

[14] Naney MT. Phase-Equilibria of Rock-Forming Ferromagnesian Silicates in Granitic Systems, American Journal of Science, vol. 283, 10, pp.993-1033, 1983.

[15] Johnston $\mathrm{AD}$, Wyllie PJ. Interaction of granitic and basic magmas: experimental observations on contamination processes at $10 \mathrm{kbar}$ with $\mathrm{H} 2 \mathrm{O}$, Contributions to Mineralogy and Petrology, vol. 98, 3, pp.352-362, 1988.

[16] Hammarstrom JM, Zen Ea. Aluminum in hornblende: An empirical igneous geobarometer, American Mineralogist, vol. 71, 11-12, pp.1297-1313, 1986.

[17] Hollister LS; Grissom GC; Peters EK; Stowell HH, Sisson VB. Confirmation of the empirical correlation of $\mathrm{Al}$ in hornblende with pressure of solidification of calc-alkaline plutons, American Mineralogist, vol. 72, 3-4, pp.231-239, 1987.

[18] Johnson MC, Rutherford MJ. Experimental calibration of the aluminum-in-hornblende geobarometer with application to Long Valley caldera (California) volcanic rocks, Geology, vol. 17, 9, pp.837-841, 1989.

[19] Schmidt MW. Amphibole composition in tonalite as a function of pressure: an experimental calibration of the Al-in-hornblende barometer, Contributions to Mineralogy Petrology, vol. 110, 2, pp.304-310, 1992.

[20] Mutch EJF; Blundy JD; Tattitch BC; Cooper FJ, Brooker RA. An experimental study of amphibole stability in low-pressure granitic magmas and a revised Al-in-hornblende geobarometer, Contributions to Mineralogy and Petrology, vol. 171, 10, pp.85, 2016. 